\title{
Dental Anxiety: Etiology and Treatment Options
}

\author{
Milica Jovanović-Medojević ${ }^{1}$, Jelena Nešković ${ }^{1}$, Aleksandar Medojević ${ }^{2}$ \\ ${ }^{1}$ University of Belgrade, Faculty of Dental Medicine, Department of Restorative Dentistry and Endodontics, Belgrade, Serbia; \\ ${ }^{2}$ Institute for Health Protection Ministry of Internal Affairs, Belgrade, Serbia
}

\begin{abstract}
SUMMARY
Dental anxiety might be the cause of serious health problems. Avoiding dental visits can lead to complications with functional, esthetic and sociological consequences. In order to have a simple and efficient dental procedure, it is very important to diagnose dental anxiety and to react adequately. The aim of this paper is using available literature to present most frequent causes, consequences as well as treatment options for dental anxiety. Treating dental anxiety and choosing the right treatment is not always easy, however, it is important for dental practitioners to be able to assess patient's behavior, possible causes of such behavior and select adequate therapy methods. Individual approach is very important as well as timely recognition and gradation of dental anxiety in order to apply adequate and successful dental treatment.
\end{abstract}

Keywords: dental fear; dental anxiety; etiology; therapy

\section{INTRODUCTION}

Dental fear is a significant social problem and it is present both in children and adults. Despite technological development and modern approach to prevention and therapy of oral diseases, dental fear is still one of main reasons why people neglect oral health. Fear of dental treatment could be the cause of serious health problems since avoiding dental visits undoubtedly leads to complications regarding the treatment of impaired oral tissue [1]. Relationship between the patient and dental practitioner where patient's anxiety dominates, might trigger serious issues (for both the patient and the practitioner) that could lead to misdiagnosis and inappropriate dental treatment [2].

The term "fear of dentist" includes dental anxiety, dental fear and dental phobia [3]. Dental anxiety is the most benign type of fear of dentist. It is the state of apprehension that something unpleasant is going to happen in relation to dental treatment and it is coupled with a sense of losing control $[3,4]$. It usually precedes facing an object or situation that causes fear. Dental fear is an active reaction to a familiar danger, i.e. object or situation, since it appears among the persons who already had adverse experience with dental treatment and who anticipate the same scenario [5]. Worry and fear could easily trigger dysfunction of psychological, cognitive and emotional components of behavior in these persons [6]. Dental phobia is the most intensive form of fear of dentist. In comparison with excitement and fear, phobia is a clearly defined diagnosis by appropriately skilled psychologists and psychiatrist. It is a mental disorder with very pronounced fear or avoidance of a certain object or situation that significantly obstructs patient's functioning or causes major emotional stress $[5,6]$.

Relationship between fear and pain is also very important for dental practitioners. Physiological processes usu- ally trigger pain. In addition, it might also have a strong cognitive component so that patients with dental anxiety have exaggerated expectations of pain, i.e. exaggerated pain sensation in general $[7,8,9]$. Therefore, dental practitioners should be aware of pain complexity usually coupled with dental fear.

Due to extreme fear of dental treatment, psychological reactions are very common in dental office. The most common reactions are palpitations, rapid heartbeat, high blood pressure, sweating, feeling of discomfort or stomach sickness, shortness of breath, anxiety and trembling. Psychological reactions usually precede syncope although they can often appear independently, prior dental treatment.

The aim of this paper is using available literature to present the most frequent causes, consequences and treatment options for "dental fear".

\section{PREVALENCE OF DENTAL ANXIETY}

Regardless of advances in technology and methods of dental treatment, the prevalence of dental anxiety has not decreased significantly $[1,5,6,10]$. The prevalence of patients with high anxiety level varies, but it is believed that dental anxiety in North America population ranges from $10 \%$ to $20 \%$. Other studies show that prevalence of dental anxiety in different population ranges from $4 \%$ to $30 \%[1,5,10-13]$. Avoiding dental treatment due to dental fear is present in 6-15\% of adult world population [11]. Haiser et al. [11] state that $4-20 \%$ of adult patients express high dental anxiety while $2-3 \%$ of adults express avoidance of dental treatment similar to phobia. Enkling et al. [14] presented the prevalence of dental treatment fear of $11 \%$ in Germany, while Norwegian study showed $10 \%$ [5]. Furthermore, every third woman in subpopula- 
tion between 30 and 45 year of age shows high degree of dental fear $[12,13,15]$. Hmud and Walsh [16] stated that fear reduces with age while other studies have not established the correlation between age and fear. Correlation between socioeconomic status, education and fear has also not been clearly defined [16].

\section{CAUSES OF DENTAL ANXIETY}

Many studies support the thesis that pain or fear of pain is the primary cause of dental anxiety. This is confirmed by the fact that patients with high degree of anxiety are much more sensitive to pain $[17,18]$. Bare and Dundes [19] described numerous causes of dental fear: previous painful experiences, stories heard from other people, fear of pain, fear of needle and anesthesia, fear of sounds produced by dental drills, fear of criticism regarding teeth condition, fear of blood, fear of choking and gagging, feeling of vulnerability, loss of control i.e. impossibility to prevent uncomfortable situation, fear of unknown, some people even feel discomfort caused by distinctive odors in dental office. Even the act of intraoral local anesthesia application is for many anxious patients the most stressful and frightful moment whereas the sound of drill is the major cause of fear [20].

Many psychological conditions include dental anxiety (obsessive-compulsive disorder, fear of microbes, agoraphobia and depression) [21-27]. Increased dental anxiety is characteristical for patients who were the victims of abuse in the past. Children and women who suffered abuse of any kind usually subconsciously keep in their memory feelings related to that horrifying event. Dental treatment might trigger interaction between momentary and repressed event, therefore these patients avoid dental treatment because of negative associations and feeling of losing control. Persons suffering from posttraumatic stress disorder (PTSD) regardless of its cause may show increased dental anxiety as well. These patients might easily develop phobia followed by nightmares where dental practitioner has the leading role.

Even though there is no genetic basis for fear of dentist, it is proved that mutation of gene MC1R decreases the efficiency of anesthetic solution in dentistry. Persons with mutation of gene MC1R, usually characteristic for people with naturally red hair, need $20 \%$ larger dose of anesthetics than usual. Therefore, persons with such genetic variations show greater fear of dental treatment [28]. Fear of dental treatment is ranked $4^{\text {th }}$ among other situations that cause fear [29]. Aartman [30] studied various types of dental treatments and reported that tooth extraction causes the greatest level of anxiety among the patients. Tooth extraction is followed by the treatments that include use of handpieces and rotary instruments.

Corah's Dental Anxiety Scale is used to assess patient's level of fear (DAS-R, dental anxiety scale). It consists of four questions, each question containing 5 answers. Answers are scored according to 5-point Likert Scale $(\mathrm{a}=1$, $\mathrm{b}=2, \mathrm{c}=3, \mathrm{~d}=4, \mathrm{e}=5$ ), where the degree of anxiety is calculated according to the sum of scores: 0-9 not at all,
9-12 somewhat, 13-14 very much, 15-20 extremely [31]. Nowadays, the most acceptable scale is modified MDAS scale per Wong [32], which contains 8 questions about various dental procedures (including physiological, cognitive, emotional and behavioral components of dental anxiety). It also uses 5-point scale to assess the anxiety level that ranges from relaxed to very anxious.

Physiological reactions to anxiety during dental treatment include increased blood pressure, rapid breathing, fever, whereas high heart rate is a very useful factor for assessing the level of anxiety $[33,34]$. Literature suggests the use of radial immunodiffusion (laboratory technique for determining immunoglobulin concentration) to demonstrate the effectiveness of anxiety treatment methods by measuring the level of antibody known as Secretory Immunoglobulin A (S-IgA) that is considered stress marker in patients with dental anxiety [33].

\section{CONSEQUENCES OF DENTAL ANXIETY}

Literature has shown significant correlation between anxiety and poor oral health, poor oral hygiene and esthetics. That inevitably generates poor quality of life in general, coupled with major emotional, psychological and social problems. Dental anxiety is associated with increased level of caries and behavioral management problems in children [19, 35]. The study from 2003 conducted by Norwegian researchers shows that persons with high level of dental anxiety have statistically poorer oral health in terms of decayed and missing teeth, as well as oral dysfunction compared to the patients who do not suffer from dental anxiety [5]. Feared patients find dental visits extremely stressful and decide to avoid them. Often, they turn to "natural remedies" [1]. Such behavior usually leads to irregular dental visits with only emergency dental treatment or even sometimes total avoidance which leads to deterioration of oral and general health as well as associated feelings of anxiety, shame and inferiority.

\section{DENTAL ANXIETY TREATMENT OPTIONS}

Due to widespread dental anxiety, clinicians should be trained to recognize predisposition, etiology and dental anxiety treatment options [36]. If dental fear and anxiety are not diagnosed and properly treated, feared patients enter the vicious circle, as avoiding dental visits significantly worsens their problems $[20,30]$. Even though dental anxiety questionnaire is highly recommended, its use in everyday practice is limited $[36,37]$. In order to respond adequately, it is necessary to properly diagnose dental anxiety $[37,38]$, since that significantly increases the probability for successful treatment of feared patients [39].

Dental anxiety is the mildest form of fear of dentist that can be easily solved if trusting practitioner-patient relationship is established i.e. if patient is provided realistic information about dental treatment [40]. An additional problem represents the fact that in the age of information, patients usually refer first to magazines and internet 
that could cause additional, adverse consequences due to wrong and malevolent information. Through conversation, the patient should be encouraged and explained the necessity of dental procedure. That is usually enough to increase patient's pain threshold that is the main cause of dental anxiety. Greater dental anxiety may require more complex forms of therapy [40]. If conversation is not sufficient to achieve the result, it is necessary to postpone the treatment or apply pharmacological support (nitrogen oxide or oral sedation) or to use various techniques such as distraction, relaxation or other methods. High level of dental anxiety may necessitate some form of cognitivebehavioral interventions (best by referral to psychologists and psychiatrists), such as systemic desensitization, cognitive restructuring or hypnosis [5]. If there is an indication for urgent dental treatment and there is no time for adequate preparation of patient with high dental anxiety level, interventions could be performed with application of intravenous sedation, conscious sedation or even general anesthesia [41, 42]. In some cases, especially if patient's oral status is considerably deteriorated, the first dental treatment under sedation may be indicated [43].

Gaining trust in dental team is according to Bernson et al. [44] very important to successfully neutralize dental anxiety. According to their study, two out of four anxious patients confirmed that trustfull interaction with the dentist and possibility to control the situation helped them complete dental treatment. Good communication between dental practitioner and patient is crucial for productive working relationship that results in adequate clinical care. Studies conducted by Corah et al. [45] and Hamasaki et al. [46] showed that efficient mutual interaction, understanding of patient's concerns, active listening with empathy and adequate, pleasant voice decrease patient's anxiety [47]. Information obtained from practitioner could be two-dimensional i.e. information obtained prior to the treatment explaining the treatment, length of treatment, recovery or information provided by practitioner during the treatment [48]. That information is sensory information explaining patients what they can expect to feel (pressure, vibration), what part of procedure will happen, administration of anesthetics, beginning of cavity preparation. Technique "Tell-Show-Do" has the greatest application in pediatric dentistry, though it is often applied when dealing with anxious patients since it encourages the sense of control and predictability of the treatment [48-52]. During dental treatment, it is necessary to make frequent and longer breaks that would relieve the pressure on patient and enable good quality of care. Patient and practitioner could agree on signaling system used by patient if it is necessary to stop the treatment or if patient feels pain. This builds trusting relationship. "Positive reinforcement" of patients with small, tangible rewards or verbal acknowledgement may provide encouragement for cooperation and appropriate behavior, even though it is not scientifically proved [5]. Verbal reinforcement with short breaks (5-15 seconds) during the treatment often results in calm and cooperative patient [53]. If dental treatment implies painful reaction, an anesthetic solution should be administered to patient, (provided that there are no contraindications), since psychological reactions are often triggered by fear of pain [53].

It has been confirmed that focusing attention on visual and auditory stimuli in dental office or waiting room might be beneficial for patients with mild to moderate dental anxiety. Modern dental office is equipped with video or DVD or even special 3D video glasses for watching movies, video clips or even playing video games during dental treatment. Prabhakar et al. [54], have found that such distractions reduce dental anxiety, while patients who experienced such treatment insisted on having the same treatment during following visits. This program is very popular among younger patients with mild to moderate level of dental anxiety [55]. Music might be an alternate treatment option as it has been used in different medical fields to meet physiological, psychological and spiritual needs of patients. Anxyolitic effect of music has been studied in the last 20 years in a variety of medical patients, mostly surgical, cardiac and oncology patients [1]. It may be used as active musicotherapy or passive listening of soothing, relaxing music in the waiting room or during dental procedure $[55,56,57]$.

One of ways to treat dental anxiety in patients could be detailed description of dental procedure, pharmacological strategies including benzodiazepines and antidepressants, application of bioenergy, hypnosis and behavioral therapy [3]. Behavioral therapy is sometimes more benefitial than anxyolitic application, since patients usually prefer nonpharmacological therapy $[52,58]$. Most of behavioral treatments include components based on systematic desensitization and use of relaxation to neutralize and reduce fear during gradual exposure to the treatment [59]. Bergen and Kol have presented a study where they described cognitive therapy vs. muscular relaxation to reduce fear [60].

Application of acupuncture prior to dental visit could be an efficient method for reducing anxiety and fear [61]. Acupuncture is traditional Chinese technique (gained acceptance by WHO in 1975) that differentiates 12 main meridians and 361 acupuncture points on human body. Point KI3 located on the inner side of the foot, halfway between the Achilles tendon and the side of the anklebone, is used to reduce pain. For mild anxiety level it is sufficient to perform the treatment prior to dental visit, while in case of severe anxiety and fear, it is necessary to make an assessment and individual treatment plan which consists of 3-10 treatments [61].

There is a study supporting breathing exercise for reducing patient's anxiety [39]. Physiological changes following relaxation and diaphragmatic breathing are widely used in stressful situations and they are especially efficient in reduction of experienced pain [62]. This is, perhaps, not surprising since dental literature confirms the association between greater anxiety and increased pain perception [63-66]. Fear is under control of sympathetic nervous system that decreases pain threshold [67]. There are controlled breathing techniques; Milgrom et al. [39] described one where patient takes slow but deep breaths holding each breath for approximately 5 seconds before slowly exhaling. Slow and steady breathing for 2-4 minutes reduces patient's heart rate and makes anxious patients 
noticeably more comfortable [5]. Progressive muscle relaxation is proved to reduce dental fear and anxiety, in general [68]. It is basic principle of physiology that explaines when a muscle is tensed, releasing tension causes muscle relaxation (breathing becomes slower and deeper, heart rate and blood pressure decline, vasodilatation in small capillaries of extremities might become noticeable, patient has the sense of calmness and ease) [69]. This procedure is relatively simple, but it requires that patients practice at home (once or twice per day for two weeks) [39].

Cognitive restructuring aims to alter and restructure negative cognitions and enhance individual's control over such thoughts. This process includes identification of wrong and negative thoughts and interpretations often associated with dental fear, challenging patient's evidence for them, and then replacing them with more realistic thoughts $[68,70]$. Clinical psychologists use this specific method but dental practitioners can use this technique as well. Systemic desensitization is a method of gradual exposure to fear and involves slowly exposing a patient to the situations that have negative connotation and to which the patient reacts with the sense of fear and discomfort. This method is effective in post-traumatic stress disorder. The patient is exposed to certain situations with intensity defined by patient's therapist, in controlled environment in order to learn how to most effectively control patient's thoughts in given situations. This method implies gradual stress exposure while encouraging patient to use relaxation techniques to reduce fear (e.g. if patient is fearful of needle, dental practitioner gradually and slowly expose patient to the idea of dental anesthesia). Hakeberg et al. [71] conducted a ten-year study that showed systemic desensitization superior to pharmacological treatment with diazepam. The application of this method usually includes the use of computer and video presentations that will gradually expose patients to different procedures. Hypnosis may be applied as a method for reduction of dental anxiety but only with patient's request and consent. During hypnosis, the therapist enters certain parts of consciousness while focusing on dental anxiety, also change patient's unpleasant experience and make following dental visits easy [20]. In some cases, Freud's phobia therapy is very efficient.

If dental practitioner thinks that the treatment is not possible without sedation, pharmacological method is usually applied. Premedication is commonly performed with sedatives and anxiolytics. Benzodiazepines are preferred since they cause CNS depression. In that case, it is possible to perform dental treatment and keep verbal communication with the patient. Diazepam $5-10 \mathrm{mg}$ is a drug of choice. Diazepam is used 1-2 hours prior to the intervention and it causes mild pre-operative calming of patient and reduction of anxiety immediately prior to intervention [72]. Sedation may be applied orally, nasally, sublingually, intramuscularly, rectally or by inhalation. It is recommended that premedication is performed one hour prior to intervention, in dental office. Inhalation sedation includes the use of inhalation device that mixes two gases - oxygen and nitrous oxide - in small concentrations $(20-50 \%)$, for 10 to 15 minutes. Inhalation nasal mask is used for application. The application begins with pure $\mathrm{O}_{\text {, }}$, then nitrous oxide, and at the end, pure oxygen again [72]. General anesthesia is indicated in case of pathological fear of dentist (phobia), as well as in case of disabled patients [72]. Anesthesia with intubation is very common and it is usually performed by a team of dental practitioner, anesthesiologist, and sometimes, specialists in medical fields depending on patient's diagnosis. Naturally, patients with extreme degree of dental fear should first receive psychiatric treatment in non-dental setting. Treating dental phobia, which is the most complicated dental anxiety may be long and difficult. Only psychotherapist and psychiatrist perform it while dental practitioner should recognize and refer patient.

\section{CONCLUSION}

Fear of dentist should not cause avoiding dental treatments. Not having regular follow-up examinations may multiply potential oral problems and make them even more complex. Small caries lesions tend to become worse and inevitably damage dental pulp making endodontic intervention necessary, which is more complicated and expensive. Also, gum inflammation not treated adequately and on time could lead to periodontal problems and tooth loss with functional, esthetic and sociological consequences.

Key to success in neutralizing dental fear is trustful relation established between patient and dental practitioner. Therapists should fully understand patient's stress, have patience and time to listen the patient and recognize the cause of such condition. In addition, dental practitioners have to be skilled and educated to treat such patients. Individual approach to each patient, timely recognition and gradation of dental anxiety are necessary in order to perform adequate and successful treatment.

\section{REFERENCES}

1. The Joanna Briggs Institute. Music interventions for dental anxiety in pediatric and adult patients. Best Practice. 2011; 15:1-4.

2. Parkin SF. The effect of ambient music upon the reactions of children undergoing dental treatment. ASDC J Dent Child. 1981; 48:430-2. [PMID: 6946085]

3. Moola S, Pearsons A, Hagger C. Effectivenesses of music interventions on dental anxiety in pediatric and adult patients: a systematic review. JBI Library System Rev. 2011; 9:588-630.

4. Satoh Y, Nagai E, Kitamura K, Sakamura M, Ohki K, Yokota S, et al. Relaxation effect of an audiovisual system on dental patients. Part 2. Palus-amplitude. J Nihon Univ Sch Dent. 1995; 37:138-45. [PMID: 7490606]

5. Armfield J M, Heaton LJ. Management of fear and anxiety in dental clinic: a review. Aust Dent J. 2013; 58:390-407. [DOI: 10.1111/adj.12118] [PMID: 24320894]

6. American Psychiatric Association. Diagnostic and Statistical Manual and Mental Disorders. 4th ed. Washington, DS: American Psychiatric Association; 2000.

7. van Wijk AJ, Hoogstraten J. Anxiety and pain during dental injections. J Dent. 2009; 37:700-4. [DOI: 10.1016/j.jdent.2009.05.023] [PMID: 19556053]

8. van Wijk AJ, Makkes PC. Highly anxious dental patients report more pain during dental injections. Br Dent J. 2008; 205:E7; discussion 142-3. [DOl: 10.1038/sj.bdj.2008.583] [PMID: 18596822] 
9. Maggirias J, Locker D. Psychological factors and perceptions of pain associated with dental treatment. Community Dent Oral Epidemiol. 2002; 30:151-9. [DOI: 10.1034/j.1600-0528.2002.300209.x] [PMID: 12000356]

10. Gaberson KB. The effect of humorous and musical distraction of of preoperative anxiety. AORN J. 1995; 62:784, 786-8, 790-1. [DOI: 10.1016/S0001-2092(06)63531-X] [PMID: 8534077]

11. Haiser RM, Chiles K, Fudge M, Gray SE. The use of music during the immediate postoperative recovery period. AORN J. 1997; 65:777-8, 781-5. [DOI: 10.1016/S0001-2092(06)62999-2] [PMID: 9093740]

12. Cooke M, Chaboyer W, Schluter P, Hiratos M. The effects of music on preoperative anxiety in day surgery. J Adv Nurs. 2005; 52:47-55. [DOl: 10.1111/j.1365-2648.2005.03563.x] [PMID: 16149980]

13. Podder L. Effects of music therapy on anxiety levels and pain perception. Nurs J India. 2007; 98:161. [PMID: 18179127]

14. Enkling N, Marwinski G, Johren P. Dental anxiety in a representative sample of representative sample of residents of a large German city. Clin Oral Investig. 2006; 10:84-91. [DOI: 10.1007/s00784-006-0035-6] [PMID: 16477408]

15. Armfield JM, Spencer AJ, Steward JF. Dental fear in Australia: who's afraid of the dentist? Aust Dent J. 2006; 51:78-85. [DOI: 10.1111/j.1834-7819.2006.tb00405.x] [PMID: 16669482]

16. Hmud R, Walsh LJ. Dental anxiety: causes, complications, management approaches. J Minim Interv Dent. 2009; 2:67-78.

17. Bereziewicz WU. The applications of an individual music program in patients with anticipatory anxiety in dental treatment [doctoral thesis]. Krakow: Jagiellonian University; 2011.

18. Lahmann C, Schoen R, Henningsen P, Ronel J, Muehlbacher M, Loew $\mathrm{T}$, et al. Brief relaxation versus music distraction in the treatment of dental anxiety: a randomized controlled clinical trial. J Am Dent Assoc. 2008; 139:317-24. [DOI: 10.14219/jada.archive.2008.0161] [PMID: 18310736]

19. Bare LC, Dundes L. Strategies for combating dental anxiety. J Dent Educ. 2004; 68:1172-7. [PMID: 15520236]

20. Weirner AA. The Fearful Dental Patient: A Guide to Understanding and Managing. Ames: Wiley-Blackwell; 2011.

21. Armfield JM. Towards a better understanding of dental anxiety and fear: cognitions vs. experiences. Eur J Oral Sci. 2010; 118:259-64. [DOI: 10.1111/j.1600-0722.2010.00740.x] [PMID: 20572859]

22. Heaton LJ, Mancl LA, Grembowski, Armfield JM, Milgrom P. Unmet dental need in community-dwelling adults with mental illness: results from the 2007 Medical Expenditure Panel Survey. J Am Dent Assoc. 2013; 144:e16-23. [DOl: 10.14219/jada.archive.2013.0122] [PMID: 23449910]

23. Okoro CA, Strine TW, Eke PI, Dhingra SS, Balluz LS. The association between depression and anxiety and use of oral health services and tooth loss. Community Dent Oral Epidemiol. 2012; 40:134-44. [DOI: 10.1111/j.1600-0528.2011.00637.x] [PMID: 21883356]

24. Locker D, Poulton R, Thomson WM. Psychological disorders and dental anxiety in young adult population. Community Dent Oral Epidemiol. 2001; 29:456-63. [DOI: 10.1034/j.1600-0528.2001.290607.x] [PMID: 11784289]

25. Armfield JM, Pohjola V, Joukamaa M, Mattila AK, Suominen AL, Lahti SM. Exploring the association between somatization and dental fear and dental visiting. Eur J Oral Sci. 2011; 119:288-93.

[DOI: 10.1111/j.1600-0722.2011.00839.x] [PMID: 21726289]

26. Willumsen T. Dental fear in sexually abused women. Eur J Oral Sci. 2001; 109:291-6. [DOI: 10.1034/j.1600-0722.2001.00069.x] [PMID: 11695748]

27. Dougall A, Fiske J. Surviving child sexual abuse: the revelance to dental practice. Dent Update. 2009; 36:294-6, 298-300, 303-4. [PMID: 19585853]

28. Binkley CJ, Beacham A, Neace W, Gregg RG, Liem EB, Sessler DI. Genetic variations associated with red hair color and fear of dental pain, anxiety regarding dental care and avoidance of dental care. J Am Dent Assoc. 2009; 140:896-905.

[DOI: 10.14219/jada.archive.2009.0283] [PMID: 19571053]

29. Milgrom P, Weinstein P. Dental fears in general practice: new guidelines for assessment and treatment. Int Dent J. 1993; 43:288-93. [PMID: 8406959]
30. Aartman IHA. Reliability and validity of the short version of the Dental Anxiety Inventory. Community Dent Oral Epidemiol. 1998; 26:350-4. [DOI: 10.1111/j.1600-0528.1998.tb01972.x] [PMID: 9792128]

31. Corah NL. Development of a dental anxiety scale. J Dent Res. 1969; 48:596. [DOI: 10.1177/00220345690480041801] [PMID: 5256508]

32. Wong HM, Humphis GM, Lee GT. Preliminary validation and reliability of the Modified Child Dental Anxiety Scale. Psychol Rep. 1998; 83:1179-86. [DOI: 10.2466/pr0.1998.83.3f.1179] [PMID: 10079713]

33. Singh $\mathrm{H}$, Meshram G, Warhadpande M, Kapoor P. Effects of perceived control in management of anxious patients undergoing endodontic therapy by use of an electronic communication system. J Conserv Dent. 2012; 15:51-5. [DOl: 10.4103/0972-0707.92607] [PMID: 22368336]

34. Gawkrodger DJ. Investigation of reactions to dental materials. Br J Dermatol. 2005; 153:497-85. [DOI: 10.1111/j.1365-2133.2005.06821.x] [PMID: 16120131]

35. Lahti S, Vehkalahti MM, Norblad A, Hausen H. Dental fear among population aged 30 years and older in Finland. Acta Odontol Scand. 2007; 65:97-102. [DOI: 10.1080/00016350601058085] [PMID: 17453427]

36. Gordon D, Heimberg RG, Tellez M, Ismail Al. A critical review of approaches to the treatment of dental anxiety in adults. J Anxiety Disord. 2013; 27:365-78. [DOI: 10.1016/j.janxdis.2013.04.002] [PMID: 23746494]

37. Heaton LJ, Carson CR, Smith TA, Baer RA, de Leeuw R. Predicting anxiety during dental treatment using patients self-reports: less is more. J Am Dent Assoc. 2007; 138:188-95. [DOI: 10.14219/jada.archive.2007.0135] [PMID: 17272373]

38. Sharif MO. Dental anxiety: detection and management. J Appl Oral Sci. 2010; 18:i. [DOI: 10.1590/S1678-77572010000200001] [PMID: 20485918]

39. Milgrom P, Weinstein P, Heaton LJ. Treating Fearful Dental Patients: A Patient Management Handbook. 3rd ed. Seattle, WA: Dental Behavioral Resources; 2009

40. De Jongh A, Adair P, Meijerink-Amderson M. Clinical management of dental anxiety: what works on whom? Int Dent J. 2005; 55:73-80. [DOl: 10.1111/j.1875-595X.2005.tb00037.x] [PMID: 15880961]

41. Gazal G, Mackie IC. Distress related to dental extraction for children under general anaesthesia and their parents. Eur J Paediatr Dent. 2007; 8:7-12. [PMID: 17359208]

42. Klassen MA, Veerkamp JS, Hoogstraten J. Dental treatment under general anaesthesia: the short-term change in young children's oralhealth-related quality of life. Eur Arch Paediatr Dent. 2008; 9:130-7. [DOl: 10.1007/BF03262624] [PMID: 18793595]

43. Lundgren J, Wide Boman U. Multimodal cognitive behavioural treatment. In: Ost LG, Skaret E, editors. Cognitive Behavioural Therapy for Dental Phobia and Anxiety. Oxford: John Wiley \& Sons; 2013. p.109-118.

44. Bernson JM, Hallberg LR, Elfstrom ML, Hakeberg M. 'Making dental care possible: a mutual affair': a grounded theory relating to adult patients with dental fear and regular dental treatment. Eur J Oral Sci. 2011; 119:373-80. [DOI: 10.1111/j.1600-0722.2011.00845.x] [PMID: 21896054]

45. Corah NL, O'Shea RM, Bissell GD, Thines T], Mendola P. The dentistpatient relationship: perceived dentist behaviors that reduce patient anxiety and increase satisfaction. J Am Dent Assoc. 1988; 116:73-6. [DOI: 10.14219/jada.archive.1988.0162] [PMID: 3422668]

46. Hamasaki T, Soh I, Takehara T, Hagihara A. Applicability of both dentist and patient perceptions of dentists' explanations to the evaluation of dentist-patient communication. Community Dent Health. 2011; 28:274-9. [DOI: 10.1922/CDH_2589Hagihara06] [PMID: 22320065]

47. Geboy MJ. Communication and Behavior Management in Dentistry. Toronto: BC Decker; 1989.

48. Kent G, Croucher R. Achieving Oral Health: The Social Context of Dental Care. 2nd ed. Oxford: Butterworth Heinmann; 1998.

49. Eaton JJ, McTigue DJ, Fields HW Jr, Beck M. Attitudes of contemporary parents toward behavior management techniques used in pediatric dentistry. Pediatr Dent. 2005; 27:107-13. [PMID: 15926287]

50. Kantaputra PN, Chiewcharnvakijkit K, Wairatoanich K, Malikaew P, Aramrattana A. Children's attitudes toward behavior management techniques used by dentists. J Dent Child (Chic). 2007; 74:4-9. [PMID: 18430348] 
51. Luis de Leon J, Guinot Jimeno F, BelleT Dalmau LJ. Acceptance by Spanish parents of behaviour'management techniques used in pediatric dentistry. Eur Arch Paediatr Dent. 2010; 11:175-8. [DOI: 10.1007/BF03262739] [PMID: 20840827]

52. Muhammad S, Shyama M, Al-Mutawa SA. Parental attitude toward behavioral management techniques in dental practice with schoolchildren in Kuwait. Med Princ Pract. 2011; 20:350-5. [DOI: 10.1159/000323758] [PMID: 21576996]

53. Melamed BG, Williamson DJ. Programs for the treatment of dental disorders: dental anxiety, and temporomandibular disorders. In: Sweet J), Rozensky RH, Tovian SM, editors. Handbook of Clinical Psychology in Medical Settings. New York: Plenum Press; 1991. p.539-566.

54. Prabhakar A, Marwah N, Raju OS. A comparison between audio and audiovisual distraction techniques in managing anxious pediatric dental patients. I Indian Soc Pedod Prev Dent. 2007; 25:177-82. [DOI: 10.4103/0970-4388.37014] [PMID: 18007104]

55. Frere CL, Crout R, Yorty J, McNeil D. Effects of audiovisual distraction during dental prophylaxis. J Am Dent Assoc. 2001; 132:1031-8. [DOI: 10.14219/jada.archive.2001.0309] [PMID: 11480629]

56. Marwah N, Prabhakar A, Raju OS. Music distraction - its efficacy in management of anxious pediatric dental patients. I Indian Soc Pedod Prev Dent. 2005; 23:168-70. [DOI: 10.4103/0970-4388.19003] [PMID: 16327136]

57. Kemper KJ, Danhauer SC. Music as therapy. South Med J. 2005; 98:282-8. [DOI: 10.1097/01.SMJ.0000154773.11986.39] [PMID: 15813154]

58. Halvorsen B, Willumsen T. Willingness to pay for dental fear treatment. Is supplying dental fear treatment socially beneficial? Eur ) Health Econ. 2004; 5:299-308. [DOI: 10.1007/s10198-004-0238-1] [PMID: 15452733]

59. Kvale G, Berggen U, Milgrom P. Dental fear in adults: a meta-analysis of behavioral interventions. Community Dent Oral Epidemiol. 2004; 32:250-64. [DOI: 10.1111/j.1600-0528.2004.00146.x] [PMID: 15239776]

60. Logan H, Baron RS, Keeley K, Law AS, Stein S. Desired control and felt control as mediators of stress in a dental settings. Health Psychol. 1991; 10:352-9. [DOI: 10.1037/0278-6133.10.5.352[ [PMID: 1935871]

61. Littl JW. Complentary and alternative medicine: Impact in dentistry. Oral Surg Oral Med Oral Pathol Oral Radiol Endod 2004; 98:137-45. [DOI: 10.1016/tripleo.2004.05.011] [PMID: 15316539]
62. Schaffer SD, Yucha CB. Relaxation and pain management: the relaxation response can play a role in managing chronic and acute pain. Am J Nurs. 2004; 104:75-6, 78-9, 81-2. [PMID: 15300063]

63. Litt MD. A model of pain and anxiety associated with acute stressors: distress in dental procedures. Behav Res Ther. 1996; 34:459-76. [DOI: 10.1016/0005-7967(96)00015-0] [PMID: 8687368]

64. Sanikop S, Agrawal P, Patil S. Relationship between dental anxiety and perception during scaling. J Oral Sci. 2011; 53:341-8. [DOI: 10.2334/josnusd.53.341] [PMID: 21959662]

65. Sullivan MJ, Neish N. Catastrophic thinking and the experience of pain during dental procedures. I Indiana Dent Assoc. 2000; 79:16-9. [PMID: 11314075]

66. Sullivan M), Neish N. Catastrophizing, anxiety and pain during dental hygiene treatment. Community Dent Oral Epidemiol. 1998, 26:344-9. [DOl: 10.1111/j.1600-0528.1998.tb01971.x] [PMID: 9792127]

67. Ayer W. Psychology and Dentistry: Mental Health Aspects of Patient Care. New York: The Haworth Press; 2005.

68. Berggren U, Hakeberg M, Carlsson SG. Relaxation vs. cognitively oriented therapies for dental fear. J Dent Res. 2000; 79:1645-51. [DOI: 10.1177/00220345000790090201] [PMID: 11023258]

69. Bracke PE. Progressive muscle relaxation therapy. In: Weiner IB, Craighead WE, editors. Corsini Encyclopedia of Psychology. 4th ed. Hoboken: John Wiley \& Sons; 2010. p.1-2.

70. De Jongh A, Muris P, ter Horst G, van Zuuren F, Schoemakers N, Makkes P. One-session cognitive treatment of dental phobia: preparing dental phobics for treatment by restructuring negative cognitions. Behav Res Ther. 1995; 33:947-54. [DOI: 10.1016/0005-7967(95)00027-U] [PMID: 7487854]

71. Hakeberg M, Berggren U, Carlsson SG. A 10-year follow-up of patients treated for dental fear. Scand J Dent Res. 1990; 98:53-9. [DOl: 10.1111/j.1600-0722.1990.tb00939.x] [PMID: 1970194]

72. Milanović J, Marković D. Strah od stomatoloških intervencija. Stomatolog. 2014; 20:12-20. 


\title{
Dentalni stres: etiologija i terapijske mogućnosti
}

\author{
Milica Jovanović-Medojević', Jelena Nešković', Aleksandar Medojević \\ 'Univerzitet u Beogradu, Stomatološki fakultet, Klinika za bolesti zuba i endodonciju, Beograd, Srbija; \\ ${ }^{2}$ Zavod za zaštitu zdravlja radnika MUP-a, Beograd, Srbija
}

\begin{abstract}
KRATAK SADRŽAJ
Strah od stomatoloških zahvata može biti uzrok težih zdravstvenih problema. Izbegavanje poseta stomatologu neminovno dovodi do komplikacija u lečenju obolelih oralnih tkiva, uzrokujući funkcionalne, estetske i sociološke posledice. Za uspeh stomatološke intervencije i njeno lakše izvođenje veoma su važni pravilno dijagnostikovanje dentalne uznemirenosti i odgovarajuća reakcija stomatologa. Cilj rada je bio da se na osnovu dostupne literature predstave najčešći uzroci, posledice i terapijske mogućnosti u zbrinjavanju ovog vrlo raširenog problema. Tretman dentalnog straha i izbor prave metode nisu uvek laki, pa je zbog toga za stomatologe najznačajnije da razviju veštinu procene ponašanja pacijenta, razloge njihovih problema i traženja odgovarajućih metoda lečenja. Neophodni su individualni pristup svakom pacijentu i pravovremeno prepoznavanje i gradacija dentalnog stresa, kako bi se primenila odgovarajuća i uspešna stomatološka terapija.

Ključne reči: strah od stomatologa; dentalni stres; etiologija; terapija
\end{abstract}

\section{UVOD}

Strah od stomatološke intervencije je značajan društveni problem koji je zastupljen i kod dece i kod odraslih pacijenata. Uprkos tehnološkom razvoju i savremenom pristupu u prevenciji i terapiji oboljenja usta i zuba, jedan od osnovnih razloga zanemarivanja brige o oralnom zdravlju u današnje vreme je i dalje strah od stomatologa. Strah od stomatoloških zahvata može biti uzrok težih zdravstvenih problema, jer izbegavanje poseta stomatologu neminovno vodi do komplikacija u terapiji obolelih oralnih tkiva [1]. Odnos pacijenta i stomatologa u kojem dominira uznemirenost pacijenta može dovesti do teških problema (za pacijenta, ali i za terapeuta), koji mogu otežati postavljanje pravilne dijagnoze i pružanje odgovarajućeg lečenja [2].

Pod pojmom „strah od stomatologa“ moguće je razlikovati dentalnu anksioznost, dentalni strah i dentalnu fobiju [3]. Dentalna anksioznost je najblaži oblik straha od stomatologa. To je stanje uzbuđenosti da će se nešto loše desiti u vezi sa stomatološkom intervencijom i obično je udruženo sa osećajem gubitka kontrole [3,4]. Ono najčešće prethodi susretu s objektom ili situacijom koja je uzrok straha. Dentalni strah je aktivan odgovor na poznatu opasnost, tj. objekat ili situaciju, jer se pojavljuje kod osoba koje su već imale loša stomatološka iskustva i očekuju da se to neminovno ponovi [5]. Zabrinutost i strah mogu često da dovedu do disfunkcije psiholoških, kognitivnih i emocionalnih komponenata ponašanja kod takvih osoba [6]. Dentalna fobija je najintenzivniji oblik straha od stomatologa. U odnosu na uzbuđenost i strah, fobija je usko definisana dijagnoza od strane odgovarajuće obučenih psihologa i psihijatara kao mentalni poremećaj koji sadrži izražen strah ili izbegavanje određenog objekta ili situacije koja značajno ometa funkciju pacijenata ili uzrokuje znatni emotivni stres $[5,6]$.

Odnos između straha i bola je takođe veoma značajan za stomatologe. Bol je obično aktiviran fiziološkim procesima, ali može imati i snažnu kognitivnu komponentu, pa pacijenti sa dentalnom anksioznošću imaju preterana očekivanja vezana za bol, odnosno uopšte preteran doživljaj bola [7, 8, 9]. Zato je važno da klinički lekari budu svesni kompleksnosti bola koji je obično udružen sa dentalnim strahom.

Zbog preteranog straha od stomatološke intervencije, psihičke reakcije su česta pojava u stomatološkoj ordinaciji. Ove reakcije se manifestuju pojavom palpitacija, povećanim brojem otkucaja srca u minuti, povišenim pritiskom, znojenjem, osećajem nelagodnosti ili mučnine u želucu, osećajem nedostatka vazduha, uznemirenošću i drhtanjem. Psihičke reakcije često prethode pojavi sinkope, mada se često mogu javiti i samostalno, neposredno pred stomatološku intervenciju.

Cilj ovog rada je bio da se na osnovu dostupne literature predstave najčešći uzroci, posledice i terapijske mogućnosti u zbrinjavanju ovog vrlo raširenog problema.

\section{ZASTUPLJENOST DENTALNOG STRESA}

Bez obzira na napredak tehnologija i metoda u stomatološkoj terapiji, broj osoba sa dentalnom uznemirenošću se nije značajnije smanjio $[1,5,6,10]$. Učestalost pacijenata s visokom uznemirenošću je promenljiva, ali se smatra da su dentalna anksioznost i strah od stomatološke intervencije zastupljeni kod 10-20\% severnoameričke populacije. Druge studije iznose podatke o zastupljenosti dentalne anksioznosti u različitim narodima u opsegu od $4 \%$ do čak $30 \%$ [1, 5, 10-13]. Izbegavanje stomatološke intervencije zbog straha beleži se kod 6-15\% odrasle svetske populacije [11]. Hajzer (Haiser) i saradnici [11] su ustanovili da $4-20 \%$ odraslih pacijenata ispoljava visoku dentalnu uznemirenost, a da 2-3\% pokazuje fobično izbegavanje stomatološkog lečenja. Enkling (Enkling) i saradnici [14] su u svojoj demografskoj studiji nemačke populacije zabeležili zastupljenost straha od stomatološke intervencije kod $11 \%$ ispitanika, dok je u norveškoj studiji taj strah zabeležen kod 10\% pacijenata [5]. Čak svaka treća žena starosti između 30 i 45 godina ima visok stepen dentalnog straha $[12,13,15]$. Hmud (Hmud) i Volš (Walsh) [16] su naveli da se strah smanjuje sa godinama, dok se u drugim studijama ne uočava veza između godina i straha. Povezanost socioekonomskog statusa i obrazovanja i straha nije jasno definisana [16].

\section{UZROCI DENTALNOG STRAHA}

Mnoge studije podržavaju tezu da je bol ili strah od bola primarni uzrok neodlaska stomatologu, što potvrđuje i činjenica da su pacijenti s višim nivoom anksioznosti znatno osetljiviji na bol $[17,18]$. Ber (Bare) i Dandis (Dundes) [19] kao uzro- 
ke straha od stomatološke intervencije navode brojne razloge: prethodna bolna iskustva, priče drugih osoba, strah od bola, igle, anestezije, zvukova stomatoloških aparata, kritike vezane za stanje zuba, krvi, davljenja i gušenja, zatim osećaj ranjivosti, gubitak kontrole, tj. nemogućnost stopiranja nelagodne situacije, strah od nepoznatog, a nekima smeta čak i sam miris stomatološke ordinacije. Sam čin primene intraoralne anestezije je za mnoge anksiozne pacijente najstresniji i najstrašniji trenutak, dok je zvuk bušilice ipak najveći uzrok straha [20].

Mnoga psihološka stanja sa sobom nose i dentalnu anksioznost u sklopu svojih osnovnih oboljenja (opsesivno-kompulsivni sindromi, strah od mikroba, agorafobija, depresija) [21-27]. Pojačan strah od stomatologa javlja se kod pacijenata koji su bili žrtve zlostavljanja. Deca i žene koja su pretrpela zlostavljanje bilo koje vrste obično podsvesno čuvaju taj doživljaj. Tokom stomatološke intervencije može doći do unakrsne reakcije između trenutnog i potisnutog događaja, te ovi pacijenti izbegavaju stomatološke intervencije zbog negativnih asocijacija i osećaja gubitka kontrole. Osobe koje pate od posttraumatskog stresnog poremećaja (PTSP) nezavisno od njegovog uzroka mogu pokazivati pojačan strah od stomatologa. Taj strah kod ovih pacijenata može poprimiti i fobičan karakter, praćen noćnim morama sa stomatologom kao glavnim akterom.

Ne postoji genetska osnova za strah od stomatologa, ali je dokazano da mutacija na genu MC1R dovodi do smanjenja efikasnosti anestetičkih rastvora u stomatologiji. Osobama sa mutacijom na ovom genu, koji se najčešće nalazi kod riđokosih pacijenata, potrebna je $20 \%$ veća doza anestetika za isti efekat. Zbog toga osobe koje imaju ovu varijaciju gena pokazuju veći strah od stomatološke intervencije [28]. Strah od stomatološkog tretmana je na četvrtom mestu po jačini u odnosu na druge situacije koje izazivaju strah [29]. Artman (Aartman) [30] je istražujući različite vrste stomatoloških intervencija uočio da najveći strah kod pacijenata izaziva vađenje zuba, a potom ga izazivaju intervencije koje zahtevaju korišćenje nasadnih i rotirajućih instrumenata.

Za procenu nivoa straha kod pacijenata koristi se Korahova (Corah) skala za procenu anksioznosti (engl. Dental Anxiety Scale - DAS-R), koja se sastoji od četiri pitanja, od kojih svako ima pet odgovora. Odgovori se boduju prema petostepenoj Likertovoj skali ( $a=1, b=2, c=3, d=4, e=5)$, a stepen anksioznosti se izračunava na osnovu zbira bodova: 0-9 nema anksioznosti; 9-12 umerena anksioznost; 13-14 visok stepen anksioznosti; 15-20 veoma visok stepen anksioznosti [31]. Danas je najprihvaćenija modifikovana skala MDAS po Vongu (Wong) [32], koja sadrži osam pitanja u vezi s različitim dentalnim procedurama (uključujući fiziološke, kognitivne, emocionalne i bihejvioralne komponente dentalnog stresa) i takođe koristi skalu od 5 poena da bi procenila nivo anksioznosti koji varira od opuštenog do veoma zabrinutog.

Fiziološki odgovor na anksioznost tokom lečenja zuba uključuje povećan krvni pritisak, ubrzano disanje i povišenje temperature, dok je ubrzani srčani ritam jedan od korisnih faktora za procenu nivoa anksioznosti $[33,34]$. U literaturi se predlaže da se efektivnost metoda za terapiju straha može demonstrirati kroz korišćenje radijalne imunodifuzije (laboratorijske tehnike koje se koriste da se odredi koncentracija imunoglobulina), gde se mere antitela poznata kao sekretorni imunoglobulini A (S-IgA), ali i kao markeri za stres kod pacijenata sa dentalnim strahom [33].

\section{POSLEDICE DENTALNOG STRESA}

Studije koje su se bavile problemom dentalne anksioznosti iznose značajnu povezanost postojanja straha i lošeg oralnog zdravlja, loše oralne higijene i, naravno, estetike. To neminovno vodi do lošeg kvaliteta života uopšte, s velikim emocionalnim, psihološkim i socijalnim problemima. Takođe se navodi da je dentalni strah povezan s češćom pojavom karijesa kod dece, ali i s problemom njihovog ponašanja $[19,35]$. Studija norveških istraživača iz 2003. godine pokazuje da osobe s visokim nivoom straha od stomatološke intervencije imaju statistički značajnije veći stepen narušenog oralnog zdravlja u vidu oštećenja i gubitka zuba i postojanja oralne disfunkcije od pacijenata koji se ne plaše odlaska kod stomatologa [5].Za uplašene pacijente poseta stomatološkoj ordinaciji je veoma teška i oni je uglavnom odlažu što duže mogu, pa često pribegavaju „narodnim“ lekovima [1]. To uglavnom dovodi do neredovnih poseta sa isključivo hitnim dentalnim tretmanima, a nekad čak i do potpunog izbegavanja koje može izazvati pogoršanje oralnog i opšteg zdravlja, kao i pojačanog osećanja uznemirenosti, sramote i inferiornosti.

\section{TERAPIJSKE MOGUĆNOSTI DENTALNOG STRESA}

Zbog široko zastupljenog svakodnevnog problema dentalnog straha, neophodno je kliničke lekare dobro informisati o značaju procene za predispoziciju, etiologiju i mogućnost lečenja dentalnog stresa [36]. Ako se dentalni strah i anksioznost ne dijagnostikuju i ne leče pravilno, pacijenti sa strahom mogu ući u začarani krug, jer izbegavanjem stomatologa dodatno pogoršavaju svoj problem $[20,30]$. Uprkos preporukama za korišćenje upitnika o dentalnom strahu, oni nisu primenjivani u svakodnevnoj praksi $[36,37]$. Za adekvatnu reakciju, neophodno je biti efikasan u otkrivanju dentalnog stresa [37,38], jer se time značajno povećava verovatnoća uspeha u radu s ovim pacijentima [39].

Dentalna anksioznost je najblaži oblik straha od stomatologa i srazmerno tome lako se može izbeći i umanjiti uspostavljanjem odnosa poverenja s pacijentom, odnosno njegovim dobrim informisanjem o predstojećoj stomatološkoj intervenciji [40]. Ove informacije najbolje bi bilo da pruži sam stomatolog, stičući na taj način pacijentovo poverenje. Dodatni problem je činjenica što u doba informativnih sistema pacijent obično prvo konsultuje časopise i internet, što može uzrokovati i dodatne, negativne posledice, zbog pogrešnih i zlonamernih informacija. Razgovorom treba ohrabriti pacijenta i objasniti mu neophodnost svega što je potrebno uraditi tokom stomatološkog tretmana. To je često dovoljno da podigne pacijentov prag tolerancije na bol, koji je i osnovni uzrok dentalnog straha. Veći nivo dentalnog stresa iziskuje neophodnost primene složenijih vidova terapije ovog problema [40]. Ukoliko razgovor nije doveo do željenih rezultata, potrebno je intervenciju odložiti i eventualno primeniti farmakološku podršku (kao što je azot-oksid ili oralna sedacija), ili koristiti različite tehnike poput odvlačenja pažnje, relaksacije ili nekih drugih metoda. Visok nivo dentalnog stresa zahteva primenu određenih oblika kognitivno-bihejvioralnih intervencija (najbolje upućivanjem specijalistima psiholozima i psihijatrima), kao što su sistematsko smanjivanje osetljivosti, kognitivno restrukturiranje ili hipnoza [5]. Ukoliko postoji indikacija za hitno stomatološko lečenje i nema vremena za 
odgovarajuću pripremu pacijenta s visokim nivoom dentalnog stresa, intervencije se mogu izvesti primenom intravenske sedacije, svesne sedacije ili pak u totalnoj anesteziji [41, 42]. U nekim slučajevima, posebno ako je pacijentovo oralno stanje veoma narušeno, indikovano je izvesti prvi tretman pod sedacijom [43].

Sticanje poverenja u stomatološki tim je, prema mišljenju Bernsona (Bernson) i saradnika [44], od presudnog značaja za uspeh neutralisanja dentalnog stresa. U njihovoj studiji su dva od četiri anksiozna pacijenta na pitanje šta im pomaže da izdrže kompletan dentalni tretman navela poverenje u interakciji sa stomatologom i mogućnost kontrole. Dobra komunikacija između stomatologa i pacijenta od ključnog je značaja za produktivan rad uz odgovarajuću kliničku negu. Studije Koraha (Corah) i saradnika [45], Hamasakija (Hamasaki) i saradnika [46] potvrđuju da efikasna dvosmerna interakcija, iskreno razumevanje pacijentove zabrinutosti i aktivno slušanje pacijenta, uz empatiju i pričanje blagim i prijatnim glasom, smanjuju uznemirenost pacijenta [47]. Informacije koje pacijent dobija od stomatologa mogu biti dvojake: informacije koje prethode lečenju i upoznaju pacijenta s načinom izvođenja i trajanja tretmana i oporavka nakon njega, i informacije koje stomatolog saopštava pacijentu tokom samog izvođenja tretmana [48]. To su senzorne informacije o onome šta pacijent može da očekuje (pritisak, vibracija), informacije u kojem delu stomatološke procedure se nalaze, primena anestezije, početak preparacije kaviteta itd. Tehnika „reci-pokaži-uradi“ najveću primenu ima u pedijatrijskoj stomatologiji, ali se vrlo često primenjuje i kod anksioznih pacijenata, jer na ovaj način podstiče osećaj kontrole tretmana i njegove predvidljivosti [48-52]. Tokom samog stomatološkog lečenja neophodno je praviti češće i duže pauze koje će smanjiti pritisak na pacijenta i omogućiti kvalitetniji rad. Postoji mogućnost dogovara pacijenta i stomatologa o sistemu signalizacije koje će pacijent pokazivati ukoliko je neophodan prekid rada, ukoliko se javi bol ili neki drugi simptom, što takođe još više izgrađuje odnos pun poverenja. „Nagrađivanje“ pacijenta sitnim, materijalnim nagradama ili verbalnim hrabrenjem može imati koristan podsticaj za saradnju ili odgovarajuće ponašanje pacijenta, iako za to nema konkretne naučne potvrde [5]. Verbalna podrška pacijentu uz kraće pauze u (5-15 sekundi) u radu često je nagrađena mirnim i saradljivim pacijentom [53]. Ukoliko se tokom stomatološkog zahvata očekuje bolna reakcija, pacijentu je neophodno primeniti anestetički rastvor (ako nema kontraindikacija), jer psihičke reakcije najčešće nastaju usled straha od bola [53].

Potvrđeno je da usmeravanje pažnje na vizuelne i audio nadražaje u stomatološkoj čekaonici i ordinaciji može povoljno uticati na pacijente sa blagim i srednjim nivoom straha. Savremene stomatološke ordinacije su opremljene video ili DVD uređajima, ili čak posebnim 3D naočarima, što omogućava pacijentima gledanje filmova, muzičkih spotova i igranje kompjuterskih igrica tokom samog tretmana. Prabakar (Prabhakar) i saradnici [54] su dokazali u svojoj studiji da se ovim odvraćanjem pažnje smanjuje dentalni strah, a pacijenti koji su bili podvrgnuti ovakvim uslovima rada su insistirali na istoj primeni i u narednim posetama. Ovaj program je posebno omiljen kod mlađih pacijenata sa nižim i srednjim nivoom dentalnog stresa [55].

Muzika može biti alternativna terapijska metoda koja se koristi na raznim poljima medicine i utiče na fiziološke, psiho- loške i duhovne potrebe pacijenata. Anksiolitički efekat muzike je obrađivan poslednjih 20 godina u različitim studijama i na različitim medicinskim pacijentima, najčešće hirurškim, kardiološkim i onkološkim [1]. Može se koristiti u aktivnom vidu kao muzikoterapija ili kao pasivno slušanje prijatne, opuštajuće muzike u čekaonici ili tokom izvođenja samog stomatološkog zahvata $[55,56,57]$.

Prepoznavanje i lečenje dentalne anksioznosti pacijenata može biti kroz detaljan opis dentalne procedure, farmakološku podršku koja podrazumeva uključivanje benzodiazepina i antidepresiva, primenom bioenergije, hipnoze i bihejvioralne terapije [3]. Često bihejvioralna terapija može biti delotvornija od primene anksiolitika, jer pacijenti uglavnom preferiraju nefarmakološku terapiju $[52,58]$. Većina bihejvioralnih tretmana uključuje komponente zasnovane na sistematskoj desenzitaciji i korišćenju relaksacije za neutralisanje i slabljenje straha tokom postepenog izlaganja tretmanu [59]. Bergen i Kol su u svojoj studiji prikazali kako trening muskularne relaksacije dovodi do veće redukcije straha od kognitivne terapije [60].

Primena akupunkture pre odlaska stomatologu se pokazala kao efikasna metoda u smanjenju anksioznosti i straha [61]. Akupunktura je tradicionalna kineska metoda lečenja (prihvaćena od strane Svetske zdravstvene organizacije 1975. godine) koja na telu razlikuje 12 glavnih meridijana i 361 akupunkturnu tačku. Za smanjenje bola se koristi tačka KI3, koja se nalazi na unutrašnjoj strani stopala, na pola puta između Ahilove tetive i zgloba. Kod blažih oblika je dovoljno sprovesti tretman neposredno pre odlaska stomatologu, a kod jače anksioznosti i straha potrebno je napraviti procenu i individualni plan lečenja koji uključuje 3-10 tretmana [61].

Postoji studija koja zagovara vežbu disanja u funkciji smanjenja anksioznosti pacijenata [39]. Fiziološke promene koje prate opuštajuće ili dijafragmalno disanje široko se koriste $\mathrm{u}$ svim stresnim situacijama, a posebno su delotvorne u redukciji doživljenog bola [62]. Ovo možda ne iznenađuje, jer je povezanost većeg straha i jače bolne percepcije potvrđena $u$ stomatološkoj literaturi [63-66]. Strah je pod uticajem simpatičkog nervnog sistema koji smanjuje prag nadražaja bola [67]. Postoji nekoliko tehnika kontrolisanog disanja. Tako Milgrom (Milgrom) i saradnici [39] opisuju postupak gde pacijent sporo i duboko udiše pri čemu zadržava svaki udisaj oko pet sekundi pre nego što polako izdahne. Sporo i ravnomerno disanje 2-4 minuta smanjuje srčani ritam pacijenta i pruža mu vidnu prijatnost [5]. Progresivna mišićna relaksacija dokazano značajno uopšte smanjuje stres, pa i dentalni strah [68]. Ona se zasniva na osnovnim fiziološkim principima gde kod napetih mišića smanjenje tenzije izaziva njihovo opuštanje (disanje postaje sporije i dublje, smanjuju se krvni pritisak i broj otkucaja srca, primećuje se vazodilatacija malih krvnih sudova u ekstremitetima i pacijent ima osećaj toplote i lakoće) [69]. Ovaj postupak je relativno jednostavan, ali iziskuje vežbanje pacijenta kod kuće (jednom ili dva puta dnevno u toku dve nedelje) [39].

Cilj kognitivnog restrukturiranja je ne samo da izmeni i restrukturira negativne sadržaje spoznaje, već i da poveća kontrolu pojedinca nad takvim mislima. Ovaj proces uključuje identifikaciju pogrešnih, negativnih misli i tumačenja koje su često u vezi sa dentalnim strahom, njihovo osporavanje i zatim menjanje pozitivnim realnim mislima $[68,70]$. Ovom specifičnom metodom se bave klinički psiholozi, iako postoji mogućnost obuke ovom veštinom i samih stomatologa. Sistemska desenzitacija je 
metoda postepenog izlaganja strahu i podrazumeva oblik terapije kod koje se pacijent postepeno izlaže situacijama koje imaju loše delovanje i na koje reaguje osećajem straha i nelagodnosti. Ova metoda je delotvorna kod posttraumatskog stresnog poremećaja. Pacijent se izlaže određenim situacijama čiji intenzitet određuje njegov terapeut u kontrolisanim okolnostima, da bi zatim naučio kako da na najbolji način kontroliše svoje misli u datim situacijama. Ova metoda podrazumeva postepeno izlaganje stresu uz ohrabrenje za korišćenje tehnika opuštanja, da bi se smanjio strah (npr. ukoliko se pacijent plaši igle, stomatolog ga postepeno i polako navikava na dentalnu anesteziju). Hakeberg (Hakeberg) i saradnici [71] su u svojoj desetogodišnjoj studiji dokazali njenu superiornost u odnosu na farmakološku terapiju sa diazepamom. Ova metoda se najčešće primenjuje pomoću kompjutera i prikazivanjem video-prezentacija koje polako navikavaju pacijente na procedure. Hipnoza se može primeniti kao metoda smanjenja dentalnog straha, naravno uz zahtev i saglasnost pacijenta. Tokom hipnoze terapeut ulazi u određene delove svesti usmeravajući pažnju na dentalnu anksioznost, menjajući pacijentova loša iskustva i olakšavajući naredne stomatološke tretmane [20]. U ovakvim slučajevima vrlo se efikasno primenjuje terapija na osnovu Frojdove terapije fobija.

Ukoliko stomatolog proceni da tretman nije moguć bez sedacije, najčešće primenjuje farmakološku metodu. Premedikacija se može izvesti sedativima ili anksioliticima. Prednost imaju benzodiazepini, koji dovode do depresije centralnog nervnog sistema. U tom slučaju je moguće izvođenje stomatološkog tretmana, a održana je verbalna komunikacija s pacijentom. Lek izbora je diazepam, i to 5-10 mg. Diazepam se primenjuje sat-dva pre intervencije, kada dovodi do blagog preoperacionog smirenja pacijenta i smanjenja straha neposredno pre intervencije [72]. Sedacija se može izvoditi peroralnim putem, nazalno, sublingvalno, intramuskularno, rektalno i inhalacionom metodom. Preporučuje se premedikacija u stomatološkoj ordinaciji sat vremena pre intervencije. Inhalaciona sedacija podrazumeva korišćenje inhalacionog aparata koji meša smesu dva gasa - kiseonika i azotnog oksidula - u niskim koncentra- cijama (20-50\%) u vremenu od 10 do 15 minuta. Za aplikaciju se koristi inhalaciona nazalna maska i prvo se počinje sa čistim kiseonikom, potom smesom azotnog oksidula, i na kraju se opet daje čist kiseonik [72]. Opšta anestezija je indikovana kod patološkog straha od stomatologa (fobičnih stanja), kao i kod hendikepiranih pacijenata [72]. Najčešće se koristi intubaciona anestezija, a izvodi je ceo tim koji sačinjavaju stomatolog, anesteziolog i eventualno specijalisti medicinskih grana u zavisnosti od dijagnoze pacijenta. Naravno, najbolje je pacijente $s$ visokim nivoom dentalnog straha prvo podvrgnuti psihoterapiji u nestomatološkom okruženju. Terapija dentalne fobije, kao najkomplikovanijeg dentalnog stresa, može biti dugotrajna i mukotrpna. Sprovode je isključivo psihoterapeut i psihijatar, a zadatak stomatologa je da prepozna i uputi pacijenta na adekvatnu pripremu.

\section{ZAKLJUČAK}

Strah od stomatologa ne sme biti razlog za izbegavanje stomatoloških zahvata. Neodlaskom na redovne kontrolne preglede potencijalni oralni problemi mogu se samo uvećati i postati sve komplikovaniji. Manje karijesne lezije postaju sve teže i neminovno dovode do oštećenja zubne pulpe i neophodnosti izvođenja endodontske intervencije, čime produžavaju i poskupljuju stomatološko lečenje. Takođe, upale gingive koje se ne leče na pravi način i pravovremeno dovode do paradontoze i gubitka zuba, koji potom uzrokuju funkcionalne, estetske i sociološke probleme.

Ključ uspeha u neutralisanju straha od stomatološke intervencije leži u poverenju koje pacijent može steći u svom stomatologu. Terapeuti moraju imati puno razumevanja za pacijentov stres, ogromno strpljenje i vremena da saslušaju pacijenta, prepoznaju tačan uzrok ovakvog stanja, ali i stručno znanje za lečenje ovakvih pacijenata. Neophodni su individualni pristup svakom pacijentu i pravovremeno prepoznavanje i gradacija dentalnog stresa, kako bi lečenje bilo adekvatno i uspešno. 